Article

\title{
Definition of LCA Guidelines in the Geothermal Sector to Enhance Result Comparability
}

\author{
Maria Laura Parisi ${ }^{1,2} \oplus$, Melanie Douziech ${ }^{3}$, Lorenzo Tosti ${ }^{1,2} \oplus$, Paula Pérez-López ${ }^{3}$, \\ Barbara Mendecka ${ }^{2,4}$, Sergio Ulgiati ${ }^{5, *(\mathbb{D})}$, Daniele Fiaschi ${ }^{2,4}\left(\mathbb{D}\right.$, Giampaolo Manfrida ${ }^{2,4}(\mathbb{D}$ and \\ Isabelle Blanc ${ }^{3, *(D)}$ \\ 1 R2ES Lab, Department of Biotechnology, Chemistry and Pharmacy, University of Siena, 53100 Siena, Italy; \\ marialaura.parisi@unisi.it (M.L.P.); tosti@csgi.unifi.it (L.T.) \\ 2 Center for Colloid and Surface Science (CSGI), 50019 Florence, Italy; barbara.mendecka@unifi.it (B.M.); \\ daniele.fiaschi@unifi.it (D.F.); giampaolo.manfrida@unifi.it (G.M.) \\ 3 MINES ParisTech, PSL University, Centre Observation, Impacts, Energie (O.I.E.), \\ 06904 Sophia Antipolis Cedex, France; melanie.douziech@mines-paristech.fr (M.D.); \\ paula.perez_lopez@mines-paristech.fr (P.P.-L.) \\ 4 Department of Industrial Engineering, University of Florence, 50135 Florence, Italy \\ 5 Department of Science and Technology, University of Naples Parthenope, 80133 Naples, Italy \\ * Correspondence: sergio.ulgiati@uniparthenope.it (S.U.); isabelle.blanc@mines-paristech.fr (I.B.)
}

Received: 25 May 2020; Accepted: 7 July 2020; Published: 9 July 2020

check for updates

\begin{abstract}
Geothermal energy could play a crucial role in the European energy market and future scenarios focused on sustainable development. Thanks to its constant supply of concentrated energy, it can support the transition towards a low-carbon economy. In the energy sector, the decision-making process should always be supported by a holistic science-based approach to allow a comprehensive environmental assessment of the technological system, such as the life cycle assessment (LCA) methodology. In the geothermal sector, the decision-making is particularly difficult due to the large variability of reported results on environmental performance across studies. This calls for harmonized guidelines on how to conduct LCAs of geothermal systems to enhance transparency and results comparability, by ensuring consistent methodological choices and providing indications for harmonized results reporting. This work identifies the main critical aspects of performing an LCA of geothermal systems and provides solutions and technical guidance to harmonize its application. The proposed methodological approach is based on experts' knowledge from both the geothermal and LCA sectors. The recommendations cover all the life cycle phases of geothermal energy production (i.e., construction, operation, maintenance and end of life) as well as a selection of LCA key elements thus providing a thorough base for concerted LCA guidelines for the geothermal sector. The application of such harmonized LCA framework can ensure comparability among LCA results from different geothermal systems and other renewable energy technologies.
\end{abstract}

Keywords: geothermal energy; renewable resource; electricity; heat \& cooling; life cycle assessment; environmental impact; harmonization

\section{Introduction}

Geothermal energy encompasses the energy derived from the Earth's interior, be it in the form of electricity or heat. Starting from the United Nation Climate Change Conference (COP21) that took place in Paris in 2015 [1], the crucial role geothermal energy could play in future energy scenarios focused on sustainable development and in the transition towards a low-carbon economy has been definitely recognized [2,3]. Indeed, thanks to its potential constant supply for base-load power, 
geothermal energy is among the most promising renewable energy sources for electricity, heating and cooling production [4]. In 2018, 13.2 GW of geothermal energy were installed worldwide [5], for a power generation of about $90 \mathrm{TWh}$. In the same year in EU, more than $3 \mathrm{GW}$ of cumulative capacity were installed, with a $10 \%$ growth rate per year during the last 5 years [6]. An increase to $18 \mathrm{GW}$ cumulative capacity by 2024 is forecast [5], with Asia representing one-third of the global expansion, mainly through projects currently under construction in Indonesia and the Philippines, followed by Kenya. This is still ten times less than the conservative technical potential estimated by the IPCC [7]; one potential reason being that the advantages of using geothermal natural resources for power production are not yet widely known. Another reason for the relatively slow increase in the installed geothermal energy might be that the extraction of geothermal energy is complex due to the diversity of environmental conditions, which often require a specific design of technologies [3]. The composition, temperature, and state of the geothermal resource, the host rock type, or the depth at which the geothermal resource is present, have an impact on how energy is extracted from the geothermal resource [8]. In addition, the intended final use of the geothermal energy determines the types of technology that can be used. As a result, the portfolio of technologies available to extract the geothermal resource, and the technological variability, is very large. Geothermal power generation technologies can commonly be classified into dry steam, single and multi-stage flash, binary cycle (Organic Rankine Cycle, ORC), and enhanced geothermal systems (EGS) technologies [2]. Dry steam technologies can be used whenever the geothermal fluid consists only of steam. The steam is collected and then directed into a powerhouse where it propels a turbine to generate electricity. Single-flash steam technologies are implemented whenever the geothermal fluid is a mixture of liquid and gaseous components. The technology implies to first separate the mixture into distinct steam and liquid phases during a so-called flashing process. Secondly, the steam is directed to a turbine and generates electricity, before being condensed, in a third step, and finally being reinjected to the ground together with the separated liquid. The design of multi-flash steam plants is like the one of single-flash steam plants, with the sole difference that the separation of the gas and liquid phase occurs through multiple flashing processes. The design of these plants is therefore more complex, but the power output can be increased by $15-25 \%$. Binary cycle technologies use a working fluid which collects the heat from the geothermal fluid and undergoes a closed cycle to generate electricity. This type of technology is appropriate when the temperature of the geothermal fluid is too low to be used directly, typically lower than $200{ }^{\circ} \mathrm{C}$. Finally, EGS rely on a technology similar to binary cycles except that the water availability or the host rock permeability is enhanced in a preliminary step [9].

Such technological variability of geothermal systems, coupled with the peculiar geomorphological characteristics of the exploited geothermal reservoirs, result in a large range of energy outputs as well as potential environmental impacts. In their highly cited review, Bayer and co-authors [10] describe the potential environmental impacts resulting from land use, atmospheric emissions, water use, and noise disturbances. Additional potential impacts on biodiversity loss and induced seismicity are also mentioned. All potential impacts vary in intensity, depending on the implemented technology, the chemical characteristics of the resource, the local ecosystems impacted by the plant's construction, and the energy produced by the system.

Evaluating and managing the life cycle impacts of processes offers the opportunity to accelerate the transition towards sustainable production [11,12]. In this context, life cycle assessment (LCA) is particularly valuable in the decision-making process to identify and prioritize solutions according to sustainable development criteria, both in the public and private sectors. In fact, LCA, is a standardized methodology to characterize the potential environmental impacts of a system throughout its entire life cycle. As such, LCA is widely recognized as a very powerful tool to assess the environmental impacts of technological systems by investigating the advantages and drawbacks of specific designs along the whole technological chain and to allow consistent comparisons among different technologies [13].

The ISO 14040-14044 standards provide the framework for performing an LCA [14,15]. The ILCD Handbook [16], developed by the Joint Research Center of the European Commission, is based on 
the primary definition and information given in the ISO 14,040 series and supplies more detailed methodological recommendations, supporting documents and tools. However, these methodological frameworks provide general indications but do not account for specificities of energy pathways, and, more specifically, of energy systems, thus leaving the user facing a large range of choices.

The aim of this work is to present reliable methodological guidelines developed within the GEOENVI project to facilitate the application of LCA to geothermal installations. This is an important contribution for decision makers to fulfil their need for environmental performance comparability with an adequate scheme.

\section{Gaps and Inconsistencies in Current LCA Practices for Geothermal Systems}

Besides the extensive work of Bayer and co-authors in 2013 [10], two other reviews that reflect the current status of LCAs in the field of geothermal energy have been published recently $[17,18]$. These reviews highlight five major areas of improvement in the application of LCA to geothermal energy systems to enhance the consistencies and compatibility of LCA results:

(i) To date, only a few LCAs have been conducted, as highlighted by Tomasini-Montenegro et al. [18] who found only 19 studies for the different types of geothermal energy technologies. This small number of studies hinders a complete understanding of the potential environmental impact of geothermal energy systems and different technological settings.

(ii) The lack of a comprehensive overview leads, in a second point, in the difficulty of clearly understanding and explaining the large variability of the reported results. For greenhouse gas emissions, results can range from $65 \mathrm{~g} \mathrm{CO}_{2} \mathrm{eq} / \mathrm{kWh}_{\mathrm{e}}$ calculated by Frick and co-authors [19] to an average of $712.5 \mathrm{~g} \mathrm{CO}_{2} \mathrm{eq} / \mathrm{kWh}_{\mathrm{e}}$ as reported by Bravi and Basosi [20]. Such a significant variation can be related to the different technology adopted by the investigated plants (e.g., enhanced geothermal system compared to a deep single flash system, respectively).

(iii) Methodological choices can also contribute to the variability of results. In fact, Bravi and Basosi [20] included only the production phase in their system boundaries excluding therefore the drilling, construction, and decommissioning phases. On the contrary, Frick et al. [19] considered the entire life cycle. Furthermore, the two studies do not consider the same plant lifetime (i.e., 25 years for Bravi and Basosi and 30 years for Frick and co-authors). A direct comparison of these values is therefore not appropriate. Fortunately, both studies clearly report the methodological choices made. However, this is not always the case and represents a third area of improvement for LCAs of geothermal systems. In fact, Eberle et al. [17] showed that among 82 studies reporting quantitative results from individual LCAs and reviews only 29 met a determined set quality, transparency, completeness, and relevance criteria. As mentioned earlier, such reporting is essential to ensure a significant comparability of the published LCA results for geothermal systems.

(iv) As a fourth point, it can be noticed that most of the studies only consider environmental impacts in terms of the amount of greenhouse gas emitted and fail to consider other impact categories. Taking into account additional environmental impacts is however essential, especially considering the variety of potential effects as reported in Bayer et al. [10]. Some of the most extensive LCA studies were carried out by Atilgan and Azapagic [21], Karlsdottir et al. [22], Lacirignola and Blanc [23]; Marchand et al. [24], Parisi and Basosi [25], Parisi et al. [26], Yu et al. [27], Basosi et al. [28] and Tosti et al. [29]. They quantify the potential impacts of a geothermal installation on acidification, eutrophication, human health, climate change, and ecosystem quality or ecotoxicity. Other studies go a bit beyond greenhouse gas emissions by quantifying also terrestrial acidification, human health, climate change, and ecotoxicity but excluding acidification (e.g., Martínez-Corona et al. [30]).

(v) This observation leads to the last area of improvement, related to the lack of consistency in the choice of the reported impact categories. 


\section{Requirement for LCA Guidelines in the Geothermal Sector}

The five areas of improvement identified in Section 2 are due to different impediments. One of the main reasons behind the small number of published LCA studies lies in the difficulty of gathering specific technological data describing the plants and the lack of available suitable proxy values, in case primary data is missing. Furthermore, as explained in Section 2, the very high variability in the reported LCA results can be explained by their dependence on the temporal and technological characteristics of geothermal power plants, as well as on the methodological choices of LCA studies.

In summary, the inherent large technological variability of geothermal systems, the lack of accessible default values for some parameters, and the lack of guidance on methodological choices for LCAs all call for harmonized guidelines on how to conduct LCAs of geothermal systems. These guidelines shall facilitate the achievement of LCAs and ensure comparability among the studies with other renewable energy technologies. The guidelines in object would in addition ensure that published LCA results all follow a coherent reporting scheme and therefore guarantee transparency and completeness.

The guidelines were developed as part of the GEOENVI project [31], gathering experts from both the geothermal and LCA sectors, offer guidance for consistency, objectiveness, and quality to enhance comparability and credibility of LCA findings on geothermal systems.

The objective of this work is to provide a common and accepted basis to evaluate the life cycle environmental impacts of geothermal energy systems allowing a fair comparison among results from different geothermal settings and energy conversion technologies. These guidelines provide advice on (i) building life cycle inventories (LCI) of geothermal systems, (ii) choosing among the available life cycle impact assessment (LCIA) methods and the impact category indicators, and (iii) documenting the LCA reports on geothermal energy production.

These guidelines should be applied when evaluating the potential environmental impacts of a geothermal system under normal operating conditions. Risk events, which deserve specific preventive measures in the geothermal field development, normal operation, and decommissioning are not considered by the LCA approach.

\section{Proposal of Harmonized Guidelines: Crucial Aspects from the Methodological Point of View}

The present guidelines have been conceived to offer methodological recommendations and assistance on how to perform LCAs of deep geothermal systems producing electricity and/or heat/cold and can be extended to cases where chemical by-products (streams of matter) are an additional power plant output. They should therefore not be used for shallow geothermal systems which rely on the seasonal temperature difference between the air and the soil at small depth. Guidance is given on geothermal-specific parameters used as inputs in LCA, on choices in the LCI data collection, and on modelling approaches and methodological assumptions resulting in the LCIA and the interpretation and reporting of the study.

\subsection{Goal and Scope}

An LCA study of a geothermal energy production system can have different goals. Depending on the goal of the study, different modeling approaches can be employed to assess an energy system [16,32,33], ranging from an attributional to a consequential LCA. The aims and answers that can be obtained from an LCA study range from the assessment of the environmental impacts of energy production to an existing geothermal plant supplying a utility's network; to the comparison of different geothermal systems with other energy technologies (i.e., attributional approach) or the assessment of the consequences of enlarging the share of electricity from geothermal resource in the electric grid of local, regional, and national communities (i.e., consequential approach).

Regardless of the modelling approach, a distinction between foreground and background processes applies in all cases: (i) foreground processes are directly influenced by the decision maker or plant owner and the data regarding these processes are generally measured directly (primary data); (ii) background 
processes are all the other processes included in the system boundaries. The data referring to this type of process is generally retrieved from specific LCA databases (e.g., ecoinvent, GaBi database and others) (secondary data). Both foreground and background data used in an LCA study should be methodologically consistent and meet overall technological, geographical, and temporal quality requirements as much as possible.

LCA practitioners should clearly define the goal and the intended application of the LCA study, the motivation behind it, and the target audience of the study. Furthermore, the LCA report should clearly state that comparability of different LCA studies can only be accomplished if the same system boundaries and assumptions are applied.

\subsubsection{Functional Unit}

The functional unit (FU) is a quantitative measurement of the function/product to be used as a reference unit for all the material and energy input and output flows [14]. This is a key element in LCA and, for geothermal systems, it allows for consistent comparisons among different power plants. In the energy sector (including geothermal applications) two main functions can be distinguished, each with a different recommended functional unit:

- Power production only: $1 \mathrm{kWh}$ of electricity delivered to the grid or a user $\left(\mathrm{kWh}_{\mathrm{el}}\right)$;

- Heating/cooling production only: $1 \mathrm{kWh}$ of heat delivered to the grid or a user $\left(\mathrm{kWh}_{\mathrm{th}}\right)$.

It is worth to underline that when handling CHP, a multi-functional approach based on a proper allocation scheme needs to be followed, as described in Section 4.2.3.

\subsubsection{System Boundaries}

System boundaries define what processes and life cycle phases are included in the analysis. It is essential that boundaries are clearly defined within the system description and, generally, a graphical representation is highly recommended along with a sketch of the basic operation of the investigated power plant. The approach is based on the description of the "Life cycle phases of energy systems" as reported within the PCR UN CPC 171 and 173 Electricity, steam and hot/cold water generation and distribution [34], which can be considered as a balanced reference. According to this report, the system under investigation should be divided into three modules: upstream, core, and downstream, as illustrated in Figure 1.

The upstream module includes the production processes for materials and energy consumed by the core module. It is a common practice to gather secondary data from existing LCA databases (e.g., Ecoinvent, GaBi database and others) which represent average estimates. These datasets can contain aggregated data including infrastructure, transport, decommissioning, and end of life stages depending on the type of database used. Therefore, it is of paramount importance to clearly indicate the type of process and from which database it is from, including its version. A valid and well documented source of secondary data is also represented by the various EPDs developed by material and energy producers (www.environdec.com).

The core module is represented by the construction of infrastructure, operation, maintenance, and End of Life (EoL) phases of a geothermal energy conversion system. The core module must be included in an LCA study. Normally, the core module is modelled using primary data that should be directly measured or collected from reports or questionnaires and is representative of the geothermal plant (site and technology specific).

In the specific case of geothermal energy system, the core module is split into three different sub-modules:

1. the infrastructure construction phase, which should include construction works for the wells, wellheads, collection pipelines, power plant building, and all the necessary plant machinery/equipment. 
2. the operational and maintenance phase, which should include geothermal fluid exploitation, stimulation, equipment replacement, scaling prevention, drilling of additional wells, and direct emissions to air.

3. the end of life phase, which includes procedures for correct closure of the wells, and the treatment of wastes produced from all previous phases.

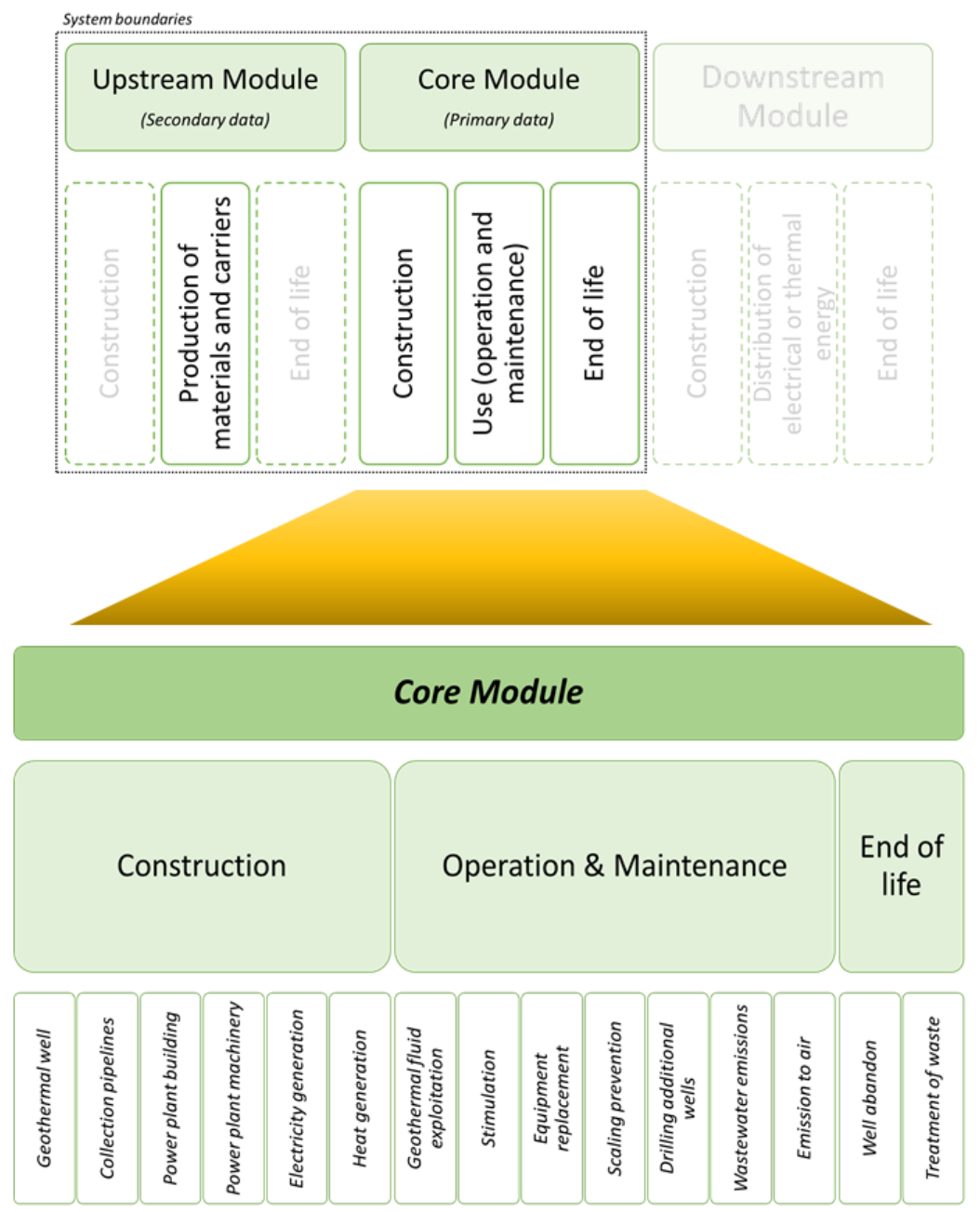

Figure 1. System boundaries for geothermal system as proposed in this work. Process units concerning each life cycle stage for the Core Module are highlighted in italic.

The downstream module consists of the distribution of the electrical or thermal energy produced, from the plant/application to the customer. The distribution network should be left out of the system boundaries. However, if the scope of the LCA includes distribution of the energy, it is highly recommended to separate the results for electricity/heat production from those of distribution to ensure comparability of results.

\subsubsection{Lifetime}

As the lifetime selection highly affects the environmental performance of the geothermal installations, a default value of 30 years is recommended to the LCA practitioners, as being a representative average duration of the activity of the plant. The same value should be applied for surface power equipment lifetime, such as the ORC, whereas a 15 years' lifetime is recommended for heat exchangers, due to physical and technical characteristics. For specific machineries, such as 
pumps handling the geofluid resource, different values can be set. The lifetime of underground resource-exposed equipment, such as electric submersible pump (ESP) and line shaft pump (LSP), should be calculated according to the mass contribution of non-condensable gases (NCG) present in the geothermal fluids, as well as the rate of replacement necessary for the maintenance assessment. Recommended values are reported in Table 1.

Table 1. Recommended values for the lifetimes (years) for ESP and LSP according to \% mass of NCG.

\begin{tabular}{ccccc}
\hline Parameter & \multicolumn{2}{c}{ ESP $\left(\mathbf{4 0 - 1 2 0}{ }^{\circ} \mathbf{C}\right)$} & \multicolumn{2}{c}{ LSP (80-160 $\left.{ }^{\circ} \mathbf{C}\right)$} \\
\hline NCG \% mass & $>0.5$ & $<0.5$ & $>0.5$ & $<0.5$ \\
\hline Replacement & $\begin{array}{c}\text { pump }+ \text { motor }+40 \% \\
\text { of column }\end{array}$ & $\begin{array}{c}\text { pump + motor }+20 \% \\
\text { of column }\end{array}$ & $\begin{array}{c}\text { pump }+40 \% \text { of } \\
\text { column }\end{array}$ & $\begin{array}{c}\text { pump }+20 \% \text { of } \\
\text { column }\end{array}$ \\
\hline Years & 3 & 5 & 4 & 7 \\
\hline
\end{tabular}

\subsection{Life Cycle Inventory}

In this section, the technical aspect of modelling a geothermal system to generate a life cycle inventory (LCI) is discussed. Detailed indications on which process design choices should be considered are given, and how to model the life cycle in terms of process selection, types of emissions, and environmental receiving compartment, management of wastes and end-of-life processes selection. As described in Section 4.1, whenever possible, the use of specific data related to the installation, that is to say, primary data, is strongly recommended. In case no specific data is available, generic data from the scientific literature and technical reports can be employed as alternative values, along with a clear explanation about the choice performed for the selection.

\subsubsection{Databases}

No specific LCI database is suggested for performing the LCA of a geothermal system. However, as the choice of the LCI database is of utmost importance, it should be driven by considerations of transparency of the documentation and availability of the unit process information and data. The database selected, its version, and an appropriate reference should always be reported.

\subsubsection{Data Quality}

A quality assessment of the used data shall be performed, and described in the project report. Among all the available tools (pedigree matrix, Monte Carlo analysis, etc.), the method described in the PEFCR Guidance version 6.3 [35] (or later) can be applied. Typical information should include: data source, year of publication, spatial and technological coverage. Potential data gaps should always be carefully reported.

\subsubsection{Allocation/Multi-functionality Hierarchy}

When dealing with multi-purpose processes, it becomes very important to allocate the impact among the different products. In the case of geothermal plants, there is a wide variability among the installations and the possible outputs:

- The production of electricity only

- The production of heat only

- Combined heat and power (or even heat, cold and power) production

- The combined production of electricity and/or heat with other potential by-products (e.g., natural gas, lithium, boron, etc.... )

In LCA, the selection of the proper allocation method can be based on different characteristics, the most common ones being the mass, economic value or energy content of the products [14]. 
According to the ILCD Handbook [16] another proper allocation method to deal with multifunctionality is based on exergy. Such an approach is useful in multigeneration geothermal applications, as the exergy methodology considers the energy quality, i.e., the exergy, contained into heat produced at different temperature levels.

In these guidelines, the following two different allocation schemes are recommended for the wide diversity of geothermal installations:

(1) If the share between the co-products is higher than $75 \%$, the system allocation scheme should apply a system expansion with a substitution model for the co-products. For CHP installations, the system allocation scheme should be based on the energy type of output products, when the ratio of the net electricity production to the net heat production exceeds $75 \%$. When applying the substitution approach [15], it is recommended to refer to the European natural gas process for the heat process and to the country-specific electricity mix for the electricity process.

(2) If the share between the co-products is lower than 75\%, the system allocation scheme should be based on the exergy content. For systems producing large amounts of heat, a comparison of the allocation scheme using either exergy or Primary Energy Saving (PES) [36] can be conducted.

\subsubsection{Modelling of the Construction Phase}

Materials and energy requirements to build subsurface, surface infrastructures, and equipment/ components, as well as the drilling of wells, are to be included in the construction phase. Recommendations on the reporting of the type of direct emissions and environmental receiving compartment (e.g., atmospheric emissions, effluents) are provided for each of these sub-systems. The use of primary data is highly recommended. When no primary data is available, average data from the scientific literature and technical reports can be used as a first approximation.

- Geothermal wells

(1) Drilling: the drilling technique adopted is typically influenced by parameters related to the geothermal reservoir such as temperature, type of host rock, gas concentration in the fluid, and depth of the reservoir. In Europe, the common drilling method applied is the well-established rotary drilling method. This method is particularly adapted when drilling into hydrothermal liquid-water and vapor dominated geothermal reservoirs is required. Rotary drilling can be applied using a diesel or electric-powered rig. Previous LCA studies have demonstrated that diesel consumption of the drilling rig has a significant impact on the LCA results $[18,23,28,37]$. Therefore, emissions to air due to in situ diesel fuel combustion (foreground data) or electricity consumption and the related background emissions data should be accounted for in this process. Water, lubricant, and other chemicals/additives are used during drilling activities. Solid and liquid waste materials are also produced, i.e., drilling mud in addition to other drilling fluid additives like cement slurry, diesel and lubricants, cleaning fluid waste, geothermal brine, or cuttings, extracted earth and rocks, and other different types of industrial waste. In particular, drilling muds are constituted of bentonite, which often include additives such as barium sulphate and other synthetic polymers. Anionic polyelectrolytes (e.g., acrylates, lignin sulfonates, polyphosphates), are commonly used as fluxing agents during drilling procedures to reduce the viscosity of the drilling fluid. The brine extracted from drilling processes contains salts as well as silica in variable amounts, depending on the type of geothermal fluid.

(2) Casing and cementing: geothermal boreholes are protected by steel and cement casings. Casing is required essentially to prevent holes from collapsing. Steel and cement utilization should, when possible, be derived from the casing design. The indirect emissions generated from the production of cement and steel should be included in the process.

(3) Stimulation: The techniques currently employed for well stimulation are hydraulic, chemical, thermal, and radial jetting stimulations. Hydraulic stimulation is the most common 
stimulation technique applied in an EGS context and is often boosted by chemical stimulation. Generally, water is always required in any stimulation and should be included as input in the process. Furthermore, all types of stimulation require electric power, which is associated with the pump functioning to maintain an adequate pressure flow. In case of chemical stimulation, the upstream production process of chemicals employed should be accounted for.

- Wellhead. Both production wells and reinjection wells usually share the same equipment that usually includes a well silencer and an aluminum well housing containing a main wellhead valve, piping and smaller valves.

- Collection pipelines (geofluid production and reinjection; NCG reinjection): the collection pipelines are made of steel, insulated with mineral wool. The pipelines are sized and designed based on the mass flow of geofluid and NCGs. It is recommended to estimate the material amount from the pipe diameter, the selected layers thickness, and density of the materials.

- Power plant building: a power plant producing only electricity includes the following facilities: switchboard plant, building for transformers, building for oil collecting pit, building for emergency power generation, gas pumping station, building for gaseous fuel, building for water supply, deionized water storage tank, building for steam generator, building for water feed pump, power house, and building for support steam generator. The buildings associated with the production of hot water for district heating are a pumping station, control house, cold water works, and heating station. It is recommended to also include here the piping between machinery and the facilities.

- Power plant machinery: the main machinery components differ depending on the geothermal power plant type (flash or binary). Materials consumption for machinery construction should, when possible, be derived from the power plant design.

- Transport to the installation site: any type of transport necessary for the exploration, the drilling, the power plant machinery and building should be reported (rail, road, or ships).

\subsubsection{Modelling of the Operation Phase}

All input and output flows in terms of materials, energy and direct emissions associated with the operation of the energy plant are included in this step. This involves direct emissions of NCGs, energy consumption from cooling and gas treatment systems as well as electricity requirements for the pumps' functioning.

- Geothermal fluid pumping: in case the geothermal flow is not self-flowing and must be pumped to the surface (downhole pump or gas lift equipment) the electricity consumption of the pumps or compressors should be accounted for. The large flow rate often associated with geothermal systems requires a significant power consumption that can exceed in some cases 1.5 MWel per well.

- ORC working fluid: most of the working fluids used in geothermal ORC systems are pure hydrocarbons, selected because of their low boiling point conditions. These fluids have a production process per unit of mass, for which it is recommended to gather the necessary LCI information. The amount of fluid used within the circuit, and the measures taken for its makeup (fugitive emissions from seals etc.) or periodic replacement, as degradation should be accounted for. The ORC working fluid determines two types of environmental impacts: indirect (upstream) cradle to industry gate emissions linked with the production of the fluid, and direct (fugitive) emissions. The upstream impacts of the ORC fluid production may be substantial for working fluids since they demand energy intensive and complex production processes requiring high-impactful inputs or producing burdening waste products. Inventory data on the manufacturing process can be modelled using background data obtained from databases and/or manufacturers. Common working fluids used in binary plants are: iso- or $n$-butane, iso- or $n$-pentane, siloxanes, $n$-hexane, benzene, refrigerants (R134a, R245fa, R124ze, R1234yf ... ), and ammonia/water mixtures.

- Direct emissions to air: the following emissions should be included in an LCA study of geothermal power plant: $\mathrm{CO}_{2}, \mathrm{CH}_{4}, \mathrm{H}_{2} \mathrm{~S}, \mathrm{NH}_{3}, \mathrm{As}, \mathrm{B}, \mathrm{Ar}, \mathrm{Hg}, \mathrm{Rn}, \mathrm{Sb} . \mathrm{H}_{2} \mathrm{~S}$ can be of a significant importance 
in some specific geothermal contexts [38]. In most of the currently available methods for the characterization of impacts there is no characterization factor associated to $\mathrm{H}_{2} \mathrm{~S}$ emission to air. Therefore, to account for this emission, it is recommended to multiply the $\mathrm{H}_{2} \mathrm{~S}$ emitted mass by 1.88 , which corresponds to an equivalent mass of $\mathrm{SO}_{2}$ emitted. In addition, the current characterization methods often have difficulties to estimate the (eco-)toxicological impact of chemicals, so that it is recommended to report the emissions of the chemicals listed above separately too.

- Working fluid loss for ORC: direct emissions result from working fluid leakage and loss, including annual leakage during the operation and working fluid loss when the system is disposed of. A simple estimation of these leakage is recommended to estimate the amount of refilling of the working fluid.

- Stimulation, hydraulic, chemical or thermal: recommendations for the modelling of the inventory are similar to the ones for the drilling of geothermal wells in the construction phase.

- Direct wastewater emissions: geothermal fluids, when not totally reinjected, become part of the liquid waste which should be inventoried as output to a treatment process. More details are given in Section 4.2.7.

- Land area: with specific reference to geothermal plants, the use of land should be reported for feeding a land use indicator. Such area depends largely on the size of the plant under examination: large plants can require a network of production and reinjection wells and considerable piping infrastructures, which should be included within the boundaries of the LCA case study.

4.2.6. Modelling of the Maintenance

- Equipment replacement: this should be accounted for by multiplying all the material inputs of a given equipment by a replacement factor. The replacement factor is calculated by dividing the power plant lifetime (years) by the specific lifetime of equipment (years), as specified in Section 4.1.3.

- Scaling residue: during operation scaling in the system (pipes, mechanical equipment ... etc.), is usually avoided by adding inhibitor chemicals to the fluid. Upstream processes for chemicals production should be inventoried as well as the residue which is obtained as result of the cleaning procedure. This residue is sent to treatment process (see Section 4.2.7).

- Drilling of additional wells: recommendations for the modelling of the inventory are similar to the ones for the drilling of geothermal wells in the construction phase.

\subsubsection{Modelling of the End of Life Stage and Waste Treatment Processes}

This step includes wells closure processes (i.e., cement and energy consumptions), as well as the treatment of wastes generated during wells drilling, stimulation activities (if needed), anti-scaling maintenance, and all other residues produced (e.g., spent sorbent from emission control systems, spent lubricants, etc.). Decommissioning of power plant buildings and dismantling, sorting and recycling of machinery's components are excluded from this phase. Following this approach, all the burdens and benefits associated with the end-of-life phases (i.e., dismantling, sorting and recycling of machinery components) are allocated to the next life cycles, thus applying the so-called cut-off principle (according to the Ecoinvent modelling schemes [39]). Secondary data can be used for waste treatment processes. If the specific treatment process is unknown, a generic landfill process should be used.

\subsection{Life Cycle Impact Assessment}

The LCIA categories to be employed for the environmental sustainability assessment of geothermal systems were selected according to the latest development of the European Commission on the recommended Environmental Footprint life cycle impact assessment methods [40]. The selected indicators are shown in Table 2. For a comprehensive description of the EF 3.0 impact assessment method the reader is directed to the official documentation [40]. In the present work, the impact categories are proposed and classified according to their level of priority in the field of geothermal energy production. 
Table 2. List of Impact Categories and their Level of Robustness Adapted from the Report on the Environmental Footprint V3.0 [40].

\begin{tabular}{|c|c|c|c|c|c|c|}
\hline Impact Category & Unit & Indicator/Method & $\begin{array}{l}\text { Version LCIA } \\
\text { Method }\end{array}$ & Source LCIA Method & $\begin{array}{l}\text { Level of } \\
\text { Priority }\end{array}$ & $\begin{array}{c}\text { Level of } \\
\text { Confidence * }\end{array}$ \\
\hline Climate change & $\mathrm{kg} \mathrm{CO}_{2} \mathrm{eq}$ & $\begin{array}{l}\text { Radiative forcing as Global Warming } \\
\text { Potential (GWP100) }\end{array}$ & $\begin{array}{l}\text { 1.0.5 (land use, land } \\
\text { use change, biogenic), } \\
1.0 .8 \text { (fossil), 4.0.16 }\end{array}$ & IPCC 2013 [41] & High & A \\
\hline Ozone depletion & kg CFC-11 eq & Steady-state ozone depletion potential & 2.0 .12 & WMO 1999 [42] & Medium & $\mathrm{A}$ \\
\hline $\begin{array}{l}\text { Human toxicity } \\
\text { cancer effects }\end{array}$ & CTUh & $\begin{array}{l}\text { Comparative toxic unit for humans as } \\
\text { provided in the USEtox 2.1. Factors have } \\
\text { been applied on inorganics and metals } \\
\text { to account for the fact that USEtox has } \\
\text { been designed for organic substances. }\end{array}$ & 1.0 .3 & Rosenbaum et al., 2008 [43] & High & $\mathrm{C}$ \\
\hline $\begin{array}{l}\text { Human toxicity } \\
\text { non-cancer effects }\end{array}$ & CTUh & $\begin{array}{l}\text { Comparative toxic unit for humans as } \\
\text { provided in the USEtox 2.1. model. } \\
\text { Factors have been applied on inorganics } \\
\text { and metals to account for the fact that } \\
\text { USEtox has been designed } \\
\text { for organic substances. }\end{array}$ & 1.0 .2 & Rosenbaum et al., 2008 [43] & High & $\mathrm{C}$ \\
\hline $\begin{array}{c}\text { Particulate } \\
\text { matter/respiratory } \\
\text { inorganics }\end{array}$ & Disease incidence & $\begin{array}{l}\text { Human health effects associated with } \\
\text { exposure to PM2.5 from the PM method } \\
\text { recommended by UNEP }\end{array}$ & 2.0 .11 & UNEP 2016 [44] & Medium & A \\
\hline $\begin{array}{l}\text { Ionising radiation, } \\
\text { human health }\end{array}$ & $\mathrm{kBq} \mathrm{U}^{235}$ & $\begin{array}{l}\text { Human exposure efficiency relative to } \\
\text { U235 using the Human health model as } \\
\text { developed by Dreicer et al. } 1995\end{array}$ & 1.0 .11 & Frischknecht et al., 2000 [45] & Medium & B \\
\hline $\begin{array}{l}\text { Photochemical ozone } \\
\text { formation }\end{array}$ & kg NMVOC eq & $\begin{array}{l}\text { Tropospheric ozone concentration } \\
\text { increases from LOTOS-EUROS as } \\
\text { applied in ReCiPe } 2008\end{array}$ & 2.0.13 & Van Zelm et al., 2008 [46] & Low & B \\
\hline Acidification & $\mathrm{Mol} \mathrm{H}^{+}$eq & Accumulated Exceedance & 1.3.9 & $\begin{array}{l}\text { Seppälä et al. (2006) [47] and } \\
\text { Posch et al. (2008) [48] }\end{array}$ & High & B \\
\hline $\begin{array}{l}\text { Eutrophication, } \\
\text { terrestrial }\end{array}$ & Mol N eq & Accumulated Exceedance & 1.2 .9 & $\begin{array}{l}\text { Seppälä et al. (2006) [47] and } \\
\text { Posch et al. (2008) [48] }\end{array}$ & Low & B \\
\hline $\begin{array}{l}\text { Eutrophication, } \\
\text { aquatic freshwater }\end{array}$ & $\mathrm{kg}$ P eq & $\begin{array}{l}\text { Fraction of nutrients reaching freshwater } \\
\text { end compartment }(\mathrm{P}) \text { using the } \\
\text { EUTREND model as } \\
\text { implemented in ReCiPe }\end{array}$ & 1.0.10 & (Struijs et al., 2009) [49] & Low & B \\
\hline
\end{tabular}


Table 2. Cont.

\begin{tabular}{|c|c|c|c|c|c|c|}
\hline Impact Category & Unit & Indicator/Method & $\begin{array}{l}\text { Version LCIA } \\
\text { Method }\end{array}$ & Source LCIA Method & $\begin{array}{l}\text { Level of } \\
\text { Priority }\end{array}$ & $\begin{array}{l}\text { Level of } \\
\text { Confidence * }\end{array}$ \\
\hline $\begin{array}{l}\text { Eutrophication } \\
\text { aquatic marine }\end{array}$ & $\mathrm{kg} \mathrm{N} \mathrm{eq}$ & $\begin{array}{c}\text { Fraction of nutrients reaching freshwater } \\
\text { end compartment }(\mathrm{N}) \text { using the } \\
\text { EUTREND model as } \\
\text { implemented in ReCiPe }\end{array}$ & 2.0.10 & (Struijs et al., 2009) [49] & Low & B \\
\hline $\begin{array}{l}\text { Ecotoxicity } \\
\text { freshwater }\end{array}$ & CTUe & $\begin{array}{l}\text { Comparative toxic units for ecosystems } \\
\text { derived from USEtox } 2.1 \text { derived from } \\
\text { the HC20 instead of the HC50. In } \\
\text { addition, factors have been applied on } \\
\text { inorganics and metals to account for the } \\
\text { fact that USEtox has been designed for } \\
\text { organic substances. }\end{array}$ & 1.0 .2 & (Rosenbaum et al., 2008) [43] & High & $\mathrm{C}$ \\
\hline Land use & $\begin{array}{c}\text { Dimensionless, } \\
\text { aggregated index of: } \\
\mathrm{kg} \text { biotic } \\
\text { production } /\left(\mathrm{m}^{2 *} \mathrm{a}\right) \mathrm{kg} \\
\text { soil } /\left(\mathrm{m}^{2 *} \mathrm{a}\right) \\
\mathrm{m}^{3} \text { water } /\left(\mathrm{m}^{2 *} \mathrm{a}\right) \\
\mathrm{m}^{3} \text { g.water } /\left(\mathrm{m}^{2 *} \mathrm{a}\right) \\
\end{array}$ & $\begin{array}{l}\text { Soil quality index (biotic production, } \\
\text { erosion resistance, mechanical filtration } \\
\text { and groundwater replenishment) based } \\
\text { on LANCA }\end{array}$ & 1.0 .10 & (Bos et al. 2016) [50] & Medium & $\mathrm{C}$ \\
\hline Water use & $\begin{array}{l}\mathrm{kg} \text { world eq. } \\
\text { deprived }\end{array}$ & $\begin{array}{c}\text { User deprivation potential } \\
\text { (deprivation-weighted water } \\
\text { consumption) from the AWARE method }\end{array}$ & 3.0.14 & UNEP 2016 [44] & Medium & $\mathrm{C}$ \\
\hline $\begin{array}{l}\text { Resource use, } \\
\text { minerals and metals }\end{array}$ & $\mathrm{kg} \mathrm{Sb} \mathrm{eq}$ & $\begin{array}{l}\text { Abiotic resource depletion from ultimate } \\
\text { reserves using CML }\end{array}$ & 1.0 .10 & $\begin{array}{l}\text { Guinée et al. (2002) [51] and } \\
\text { van Oers et al. (2002) [52] }\end{array}$ & High & $\mathrm{C}$ \\
\hline $\begin{array}{l}\text { Resource use, } \\
\text { energy carriers }\end{array}$ & MJ & $\begin{array}{l}\text { Abiotic resource depletion from fossil } \\
\text { fuels using CML }\end{array}$ & CML v4.8 & $\begin{array}{l}\text { Guinée et al. (2002) and } \\
\text { van Oers et al. (2002) }\end{array}$ & High & $\mathrm{C}$ \\
\hline
\end{tabular}

* as suggested in [37], Level A is recommended and satisfactory, Level B recommended but in need of some improvements, Level C recommended but to be applied with caution. 
The impact categories with high level of priority should always be reported in the final results of the LCA even though the models employed to calculate the potential impact might present a low level of confidence (i.e., human and ecotoxicity categories). Assistance on how to report results from toxicity categories is given in Section 4.3.1.

\subsubsection{Reporting Emissions of Inorganics with Toxicity Impacts}

Potential toxic impacts to human and environment are of utmost importance for geothermal systems and should always be included in an LCA study. In any case, the obtained results should be used more as a "flag" which indicates that a potentially harmful substance with toxic properties has been released in the environment to a certain extent. The potential toxic impact from an LCA analysis must never be associated to any real human and/or environmental risk.

The USEtox model (V 2.11) provides a database with two types of characterization factors ( $\mathrm{CFs}$ ): recommended and interim. The distinction between recommended and interim CFs reflects the level of reliability of the model calculations in a qualitative way. CFs for 'metals' are all classified as interim because of the high uncertainty related to their fate and exposure. A recommendation for these interim chemicals cannot be supported. Applying the USEtox model with only recommended CFs implies that CFs for substances like metals are missing, which is why the USEtox Team advises to use always the recommended and interim USEtox CFs together [53]. However, if the emission of a substance characterized with interim CF dominates the overall toxicity impact, the LCA results must be carefully interpreted because of the high level of uncertainty. Metal emissions, for example, are all modeled with interim CFs and, whenever present in life cycle inventories, tend to dominate the toxicity effects over organic substances by several orders of magnitude. In these cases, it is advisable to apply a sensitivity analysis based only on the recommended CFs to see how the results, and possibly the conclusions, change.

\subsection{Interpretation and Reporting of Results}

According to the ISO standards on LCA $[14,15]$, interpretation is the final phase of the LCA procedure, in which the results of an LCIA are summarized and critically discussed as a basis for conclusions, recommendations, and decision making in accordance with the definition of the goal and scope of the study. The results should report:

- any single airborne, waterborne and soilborne emissions enabling the interpretation of the impacts

- the distribution of the impacts whether Direct or Indirect Impacts enabling to differentiate impacts related to background system (i.e., from producing electricity and from the production of common materials like steel and cement)

- the distribution of the impacts and any other specific emissions (e.g., inorganics emissions with toxicity impacts) by phase (construction; operation and maintenance; EoL)

Additional indicators could also be reported such as Primary Energy Saving (PES) [36] and Energy Payback Time (EPBT) [53] and are highly recommended whenever the geothermal LCA undertaken is meant for a comparison with other renewable energies.

\subsubsection{Primary Energy Saving}

PES is an indicator specifically defined for the evaluation of the benefits related to a thermodynamic energy conversion system [36]. Using an amount of primary energy input, the energy conversion system producing electricity and heat is compared to two different systems producing separately the two fixed amounts of electricity and heat services from two different primary energy sources. PES accounts for the overall primary energy saving in combined electricity and heat production. PES can also be used to balance the low energy content of heat compared to electricity and can thus be a relevant indicator for renewable energy technologies comparison. 


\subsubsection{Energy Payback Time}

Energy payback time (EPBT) is a relevant indicator defined for any renewable energy system producing electricity as the time to generate the same amount of electricity (expressed in primary energy equivalent) that was used to produce the system itself. As reported by the methodological guidelines on photovoltaic electricity from the IEA [52], It is calculated by accounting (1) the primary energy demand over all phases of the life cycle of the geothermal installation (to produce materials, to manufacture the geothermal installation, to manage the end of life, etc.) (2) the annual electricity generation by the geothermal installation and (3) the effective national grid efficiency at the location of the geothermal installation.

\subsection{Reporting and Communications}

Transparency in reporting is essential to explain the large variability observed in various published LCA studies of geothermal plants. These LCA guidelines underline all important information that should be documented in the LCA report, as in the following:

- for the goal and scope, a thorough description including the purpose of the study, the technical and modelling assumptions, current or expected technology), the type of LCA model applied (attributional, consequential, etc.), the name of the entity commissioning the study, the name of the third-party verifier, if relevant;

- for the setting of the system boundaries, which life cycle stages are included and which ones are excluded, excluded processes, assumptions related to the production of major input materials (e.g., primary and/or secondary production of steel and electricity source, if known);

- for the geothermal resource characteristics: reservoir type, geothermal fluid composition, NCG content, temperature, the site-specific power use (e.g., diesel or electricity mix), list of inorganic and metal emissions as suggested in Section 4.2.5 "Modelling of the operation phase";

- for the LCI, the database(s) used (e.g., Ecoinvent, GaBi, ELCD, Franklin, other), including the version numbers; the data quality assessment, the allocation method used;

- for the LCIA, the specific method selected or the impact category indicators used, including the version numbers;

- $\quad$ the LCA software used (e.g., Open LCA, SimaPro, GaBi, other), including the version numbers.

The following parameters shall also be reported in the captions of figures and tables showing the results of the LCA: (1) Geothermal technology (Hydrothermal with or without stimulation); (2) Type of energy conversion technology (e.g., direct or ORC); (3) Expected annual electricity/heat production or load factor (hours/year) and energy output decay; (4) Lifetime of installation (years); (5) Plant size (MW); (6) Number of wells (production and reinjection) and depth of the wells; and (7) Characteristics related to the output products: for steam: the distribution system pressure, feed and return temperature and flow rate, for hot water: the distribution system feed.

\section{Conclusions}

After the development of LCA guidelines for photovoltaics by experts contributing to the International Energy Agency [54], this work provides a first proposal for LCA guidelines specific to geothermal systems. These guidelines identify the main critical aspects of performing an LCA of geothermal systems and propose solutions and technical guidance with the intent to harmonize its application. The proposed methodological approach is based on experts' knowledge from both the geothermal and LCA sectors and was elaborated within the EU GEOENVI project. The coordination and support action GEOENVI project involves many experts from diverse sectors (e.g., universities, research institutes, industrial partners, stakeholders, decision-makers) and from several countries thus ensuring an high level of knowledge which is extended to various fields of application of the geothermal energy, including energy policies. Furthermore, several activities included within the GEOENVI project 
have the object to disseminate results and achievements to reach a large audience and to encourage experts in the sector to rely on such guidelines when performing LCA of geothermal installations.

The recommendations cover all the life cycle phases of geothermal energy production as well as the selection of the LCA key elements such as the impact assessment indicators, thus forming a very good basis for the development of coherent LCA guidelines for the geothermal sector. These guidelines are meant to pave the way towards a harmonized LCA framework that would ensure comparability among LCA results from energy technologies.

The generated LCA results applying these guidelines do contribute to a sustainability assessment of existing geothermal power plants and future projects. While LCA is the best available tool to describe thoroughly the environmental impacts of specific installations, it still lacks methods to account for some potential impacts more specific to the geothermal energy sector. The best approach would be to accompany LCA studies with other environmental assessment criteria, able to consider site-dependent matters (such as micro-seismicity, subsidence, noise, etc.) or whose evaluation involves social or qualitative acceptance (such as preservation of landscape, cultural heritage, effects on occupation and economics, etc.). In fact, the environmental impacts associated with geothermal power plants activity are in many cases object of monitoring plans for preservation of health and environment or of law prescriptions (i.e., for source emissions or air quality) or local agreements among the stakeholders (utilities, consumers, communities, local government).

Author Contributions: Conceptualization, M.L.P., I.B., P.P.-L., M.D. and L.T.; investigation, M.L.P., I.B., P.P.-L., L.T. and G.M.; data curation, M.L.P., M.D., I.B., P.P.-L., L.T., B.M., D.F. and G.M; writing-original draft preparation, M.L.P., M.D., I.B. and L.T.; writing-review and editing, M.L.P., L.T., I.B, M.D., P.P.L., B.M., G.M. and S.U.; supervision, M.L.P. and I.B.; project administration, M.L.P. and I.B.; funding acquisition, D.F., M.L.P. and I.B. All authors have read and agreed to the published version of the manuscript.

Funding: This research was funded by European Union's Horizon 2020 Framework Program grant number 818242.

Acknowledgments: M.L.P., M.D., L.T., P.P.-L., B.M., D.F., G.M. and I.B. acknowledge the European Union's Horizon 2020 Framework Program for funding Research and Innovation under Grant agreement no. 818242 (GEOENVI) for funding. Silvia Parisi is acknowledged for language editing and proofreading.

Conflicts of Interest: The authors declare no conflict of interest.

\section{References}

1. COP21 United Nation Climate Change Conference. Available online: https://ec.europa.eu/clima/policies/ international/negotiations/paris_en (accessed on 3 March 2020).

2. Shortall, R.; Uihlein, A. Geothermal Energy Technology Development Report 2018, EUR 29917 EN; European Comission: Luxembourg, 2019.

3. Shortall, R.; Uihlein, A.; Carrara, S. Geothermal Energy Technology Market. Report 2018, EUR 29933 EN; European Comission: Luxembourg, 2019.

4. IRENA. Renewable Energy Statistics 2019; IRENA: Masdar City, UAE, 2019; Volume 1, ISBN 978-92-9260-033-4.

5. International Energy Agency. World Energy Outlook 2019. Available online: https://www.iea.org/topics/ world-energy-outlook (accessed on 14 May 2020).

6. Sanner, B. Summary of EGC 2019 Country Update Reports on Geothermal Energy in Europe. In Proceedings of the European Geothermal Congress 2019, Den Haag, The Netherlands, 2019.

7. Goldstein, B.; Hiriart, G.; Bertani, R.; Bromley, C.; Gutiérrez-Negrín, L.; Huenges, E.; Muraoka, H.; Ragnarsson, A.; Tester, J.; Zui, V.; et al. Geothermal Energy. In Renewable Energy Sources and Climate Change Mitigation Special Report of the Intergovernmental Panel on Climate Change; Edenhofer, O., Pichs-Madruga, R., Sokona, Y., Seyboth, K., Kadner, S., Zwickel, T., Eickemeier, P., Hansen, G., Schlömer, S., von Stechow, C., et al., Eds.; Cambridge University Press: Cambridge, UK; New York, NY, USA, 2011; pp. 401-436.

8. Di Pippo, R. Geothermal Power Plants-Principles, Applications, Case Studies and Environmental Impact; Elsevier: Amsterdam, The Netherlands, 2015; ISBN 9780081008799.

9. Hirschberg, S.; Wiemer, S. Energy from the Earth Energy from the Earth Deep Geothermal as a Resource; Energy-Commission of the Swiss Academies of Arts and Sciences (Energy-Commission): Bern, Switzerland, 2015; ISBN 9783728136541. 
10. Bayer, P.; Rybach, L.; Blum, P.; Brauchler, R. Review on life cycle environmental effects of geothermal power generation. Renew. Sustain. Energy Rev. 2013, 26, 446-463. [CrossRef]

11. EU Communication from The Commission to The Council and The European Parliament-Integrated Product Policy Building on Environmental Life-Cycle Thinking. Off. J. Eur. Union 2003, 2003. Available online: https://eur-lex.europa.eu/legal-content/EN/TXT/?uri=CELEX\%3A52003DC0302 (accessed on 14 May 2020).

12. Garetti, M.; Taisch, M. Sustainable manufacturing: Trends and research challenges. Prod. Plan. Control. 2012, 23, 83-104. [CrossRef]

13. Turconi, R.; Boldrin, A.; Astrup, T. Life cycle assessment (LCA) of electricity generation technologies: Overview, comparability and limitations. Renew. Sustain. Energy Rev. 2013, 28, 555-565. [CrossRef]

14. ISO. International Organization for Standardization ISO 14040:2006_Environmental Management_Life Cycle Assessment_Principles and Framework 2006; ISO: Geneva, Switzerland, 2006.

15. ISO. International Organization for Standardization ISO 14044:2006 Environmental Management-Life Cycle Assessment_-Requirements and Guidelines 2006; ISO: Geneva, Switzerland, 2006.

16. European Commission. International Reference Life Cycle Data System (ILCD) Handbook: Framework and Requirements for Life Cycle Impact Assessment Models and Indicators; European Union: Luxembourg, 2010; ISBN 9789279175398.

17. Eberle, A.; Heath, G.A.; Carpenter Petri, A.C.; Nicholson, S.R. Systematic Review of Life Cycle Greenhouse Gas Emissions from Geothermal Electricity; NREL: Golden, CO, USA, 2017.

18. Tomasini-Montenegro, C.; Santoyo-Castelazo, E.; Gujba, H.; Romero, R.J.; Santoyo, E. Life cycle assessment of geothermal power generation technologies: An updated review. Appl. Therm. Eng. 2017, 114, 1119-1136. [CrossRef]

19. Frick, S.; Kaltschmitt, M.; Schröder, G. Life cycle assessment of geothermal binary power plants using enhanced low-temperature reservoirs. Energy 2010, 35, 2281-2294. [CrossRef]

20. Bravi, M.; Basosi, R. Environmental impact of electricity from selected geothermal power plants in Italy. J. Clean. Prod. 2014, 66, 301-308. [CrossRef]

21. Atilgan, B.; Azapagic, A. An integrated life cycle sustainability assessment of electricity generation in Turkey. Energy Policy 2016, 93, 168-186. [CrossRef]

22. Karlsdottir, M.R.; Feracor, J.A.; Pálsson, H.; Pálsson, O.P. Geothermal District Heating System in Iceland: A Life Cycle Perspective with Focus on Primary Energy Efficiency and $\mathrm{CO}_{2}$ Emissions. In Proceedings of the 14th International Symposium on District Heating and Cooling, Stockholm, Sweden, 7-9 September 2014.

23. Lacirignola, M.; Blanc, I. Environmental analysis of practical design options for enhanced geothermal systems (EGS) through life-cycle assessment. Renew. Energy 2013, 50, 901-914. [CrossRef]

24. Marchand, M.; Blanc, I.; Marquand, A.; Beylot, A.; Bezelgues-Courtade, S.; Traineau, H. Life Cycle Assessment of High Temperature Geothermal Energy Systems. In Proceedings of the World Geothermal Congress 2015, Melbourne, Australia, 2015; pp. 19-25.

25. Parisi, M.L.; Basosi, R. Geothermal energy production in Italy: An LCA approach for environmental performance optimization. In Life Cycle Assessment of Energy Systems and Sustainable Energy Technologies—The Italian Experience; Basosi, R., Cellura, M., Longo, S., Parisi, M.L., Eds.; Springer Verlag: Berlin, Germany, 2019; pp. 31-43, ISBN 18653529.

26. Parisi, M.L.; Ferrara, N.; Torsello, L.; Basosi, R. Life cycle assessment of atmospheric emission profiles of the Italian geothermal power plants. J. Clean. Prod. 2019, 234, 881-894. [CrossRef]

27. Yu, T.; Looijen, J.M.; van der Meer, F.D.; Willemsen, N. A life cycle assessment based comparison of large \& small scale geo-thermal electricity production systems. In Proceedings of the 5th Indonesia International Geothermal Convention \& Exhibition, Jakarta, Indonesia, 2-4 August 2017; pp. 2-4.

28. Basosi, R.; Bonciani, R.; Frosali, D.; Manfrida, G.; Parisi, M.L.; Sansone, F. Life cycle analysis of a geothermal power plant: Comparison of the environmental performance with other renewable energy systems. Sustainability 2020, 12, 2786. [CrossRef]

29. Tosti, L.; Ferrara, N.; Basosi, R.; Parisi, M.L. Complete life cycle inventory of a geothermal power plant for robust cradle-to-grave Life Cycle Assessment results. Energies 2020, 13, 2839. [CrossRef]

30. Martínez-Corona, J.I.; Gibon, T.; Hertwich, E.G.; Parra-Saldívar, R. Hybrid life cycle assessment of a geothermal plant: From physical to monetary inventory accounting. J. Clean. Prod. 2017, 142, 2509-2523. [CrossRef]

31. GEOENVI Project. Available online: https://www.geoenvi.eu/ (accessed on 3 March 2020). 
32. Tillman, A.M. Significance of decision-making for LCA methodology. Environ. Impact Assess. Rev. 2000, 20, 113-123. [CrossRef]

33. Ekvall, T.; Tillman, A.M.; Molander, S. Normative ethics and methodology for life cycle assessment. J. Clean. Prod. 2005, 13, 1225-1234. [CrossRef]

34. International EPD ${ }^{\circledR}$ System Product Group Classification: Un Cpc 171 and 173 Electricity, Steam and Hot/Cold Water Generation and Distribution 2019. Available online: https://www.environdec.com/PCR/ Detail/?Pcr=5802 (accessed on 14 May 2020).

35. European Commission-Joint Research Centre-Institute for Environment and Sustainability. Product Environmental Footprint Category 1 Rules Guidance-Version 6.3. 2018. Available online: https://ec.europa.eu/environment/eussd/smgp/pdf/PEFCR_guidance_v6.3.pdf (accessed on 14 May 2020).

36. European Commission Directive 2004/8/EC of the European Parliament and of the Council on the Promotion of Cogeneration Based on a Useful Heat Demand in the Internal Energy Market and Amending Directive 92/42/EEC. Off. J. Eur. Union 2004. Available online: https://eur-lex.europa.eu/legal-content/EN/ALL/?uri= CELEX\%3A32004L0008 (accessed on 14 May 2020).

37. Pratiwi, A.; Ravier, G.; Genter, A. Geothermics Life-cycle climate-change impact assessment of enhanced geothermal system plants in the Upper Rhine Valley. Geothermics 2018, 75, 26-39. [CrossRef]

38. Ferrara, N.; Basosi, R.; Parisi, M.L. Data analysis of atmospheric emission from geothermal power plants in Italy. Data Br. 2019, 25, 104339. [CrossRef]

39. Wernet, G.; Bauer, C.; Steubing, B.; Reinhard, J.; Moreno-Ruiz, E.; Weidema, B. The ecoinvent database version 3 (part I): Overview and methodology. Int. J. Life Cycle Assess. 2016, 21, 1218-1230. [CrossRef]

40. Fazio, S.; Castellani, V.; Sala, S.; Schau, E.M.; Secchi, M.; Zampori, L.; Diaconu, E. Supporting Information to the Characterisation Factors of Recommended EF Life Cycle Impact Assessment method; European Comission: Ispra, Italy, 2018; ISBN 9789279767425.

41. IPCC. Climate Change 2013: The Physical Science Basis. Contribution of Working Group I to the Fifth Assessment Report of the Intergovernmental Panel on Climate Change; Stocker, T.F., Qin, D., Plattner, G.-K., Tignor, M., Allen, S.K., Boschung, J., Nauels, A., Xia, Y., Bex, V., Midgley, P.M., Eds.; Cambridge University Press: Cambridge, UK; New York, NY, USA, 2013.

42. World Metereological Organization. Global Ozone Research and Monitoring Project-Report No 44 Scientific Assessment of Ozone Depletion: 1998; Global Ozone Observing System: Geneva, Switzerland, 1999.

43. Rosenbaum, R.K.; Bachmann, T.M.; Gold, L.S.; Huijbregts, M.A.J.; Jolliet, O.; Juraske, R.; Koehler, A.; Larsen, H.F.; MacLeod, M.; Margni, M.; et al. USEtox-The UNEP-SETAC toxicity model: Recommended characterisation factors for human toxicity and freshwater ecotoxicity in life cycle impact assessment. Int. J. Life Cycle Assess. 2008, 13, 532-546. [CrossRef]

44. UNEP/SETAC. Global Guidance for Life Cycle Impact Assessment Indicators Volume 1; United Nations Environment Programme: Paris, France, 2016.

45. Frischknecht, R.; Braunschweig, A.; Hofstetter, P.; Suter, P. Human health damages due to ionising radiation in life cycle impact assessment. Environ. Impact Assess. Rev. 2000, 20, 159-189. [CrossRef]

46. van Goethem, T.M.J.W.; Preiss, P.; Azevedo, L.B.; Roos, J.; Friedrich, R.; Huijbregts, M.A.J.; van Zelm, R. European characterization factors for damage to natural vegetation by ozone in life cycle impact assessment. Atmos. Environ. 2013, 77, 318-324. [CrossRef]

47. Seppälä, J.; Posch, M.; Johansson, M.; Hettelingh, J.-P. Country-dependent Characterisation Factors for Acidification and Terrestrial Eutrophication Based on Accumulated Exceedance as an Impact Category Indicator. Int. J. Life Cycle Assess. 2006, 11, 403-416. [CrossRef]

48. Posch, M.; Seppälä, J.; Hettelingh, J.-P.; Johansson, M.; Margni, M.; Jolliet, O. The role of atmospheric dispersion models and ecosystem sensitivity in the determination of characterisation factors for acidifying and eutrophying emissions in LCIA. Int. J. Life Cycle Assess. 2008, 17, 477. [CrossRef]

49. Struijs, J.; Beusen, A.; van Jaarsveld, H.; Huijbregts, M.A.J. ReCiPe 2008 A life cycle impact assessment method which comprises harmonised category indicators at the midpoint and the endpoint level-First edition-Report I: Characterisation. In ReCiPe 2008 A Life Cycle Impact Assessment Method Which Comprises Harmonised Category Indicators at the Midpoint and the Endpoint Level_First Edition-Report I: Characterisation; Goedkoop, M., Heijungs, R., Huijbregts, M., De Schryver, A., van Zelm, R., Eds.; Ruimte en Milieu: Hague, The Netherlands, 2012; pp. 59-67. 
50. Bos, U.; Horn, R..; Beck, T.; Lindner, J.P.; Fischer, M. LANCA ${ }^{\circledR}$ Characterization Factors for Life Cycle Impact Assessment, Version 2.0; Fraunhofer Verlag: Stuttgart, Germany, 2016.

51. De Oers, L.; Koning, A.; Guinee, J.B.; Huppes, G. Abiotic Resource Depletion in LCA; Road and Hydraulic Engineering Institute: Amsterdam, The Netherlands, 2002.

52. Guinée, J.B.; Gorrée, M.; Heijungs, R.; Huppes, G.; Kleijn, R.; de Koning, A.; van Oers, L.; Wegener Sleeswijk, A.; Suh, S.; Udo de Haes, H.A.; et al. Handbook on Life Cycle Assessment. Operational Guide to the ISO Standards. I: LCA in Perspective. IIa: Guide. IIb: Operational Annex. III: Scientific Background; Kluwer Academic Publishers: Dordrecht, The Netherlands, 2002.

53. Fantke, P.; Bijster, M.; Guignard, C.; Hauschild, M.; Huijbregts, M.; Jolliet, O.; Kounina, A.; Magaud, V.; Margni, M.; McKone, T.E.; et al. USEtox ${ }^{\circledR} 2.0$ Documentation (Version 1.1)_UNEP/SETAC Scientific Consensus Model for Characterizing Human Toxicological and Ecotoxicological Impacts of Chemical Emissions in Life Cycle Assessment Documentation (Version 1.1); USEtox ${ }^{\circledR}$ International Center: Lyngby, Denmark, 2017.

54. Frischknecht, R.; Heath, G.; Raugei, M.; Sinha, P.; de Wild Scholten, M. Methodology Guidelines on Life Cycle Assessment of Photovoltaic Electricity Methodology Guidelines on Life Cycle Assessment of Photovoltaic Electricity 3rd Edition, EA PVPS Task 12-Report IEA-PVPS T12-06:2016. International Energy Agency Photovoltaic Power Systems Programme. 2016. Available online: https:/iea-pvps.org/wp-content/uploads/2020/01/Task_12_-_ Methodology_Guidelines_on_Life_Cycle_Assessment_of_Photovoltaic_Electricity_3rd_Edition.pdf (accessed on 14 May 2020).

(C) 2020 by the authors. Licensee MDPI, Basel, Switzerland. This article is an open access article distributed under the terms and conditions of the Creative Commons Attribution (CC BY) license (http://creativecommons.org/licenses/by/4.0/). 